Trends in Innate Immunity 


\section{Contributions to Microbiology}

\section{Vol. 15}

Series Editors

Axel Schmidt witten

Heiko Herwald Lund 


\section{Trends in Innate Immunity}

Volume Editors

Arne Egesten Lund

Axel Schmidt witten

Heiko Herwald Lund

20 figures, 1 in color, and 8 tables, 2008 


\section{Contributions to Microbiology}

formerly 'Concepts in Immunopathology' and 'Contributions to Microbiology and Immunology'

\author{
Arne Egesten, MD, PhD \\ Section for Respiratory Medicine \\ Department of Clinical Sciences \\ Biomedical Center B14 \\ Lund University \\ Tornavägen 10 \\ SE-221 84 Lund (Sweden)
}

\section{Axel Schmidt, MD, PhD}

Professor of Clinical Microbiology

Institute of Microbiology and Virology

Private University of Witten/Herdecke

Stockumer Strasse 10

DE-58448 Witten (Germany)
Heiko Herwald, PhD

Division of Infection Medicine

Department of Clinical Sciences

Biomedical Center B14

Lund University

Tornavägen 10

SE-221 84 Lund (Sweden)

\footnotetext{
Library of Congress Cataloging-in-Publication Data

Trends in innate immunity/volume editors, Arne Egesten, Axel Schmidt, Heiko Herwald

p. ; cm. - (Contributions to microbiology, ISSN 1420-9519; v. 15)

Includes bibliographical references and indexes.

ISBN 978-3-8055-8548-4 (hard cover : alk. paper)

1. Natural immunity. I. Egesten, Arne. II. Schmidt, Axel, 1962- III. Herwald, Heiko. IV. Series.

[DNLM: 1. Immunity, Natural-physiology. 2. Immune System-physiology. W1

CO778UE v.15 2008/QW 541 T793 2008]

QR185.2.T74 2008

$616.07^{\prime} 9-\mathrm{dc} 22$

2008012887
}

Bibliographic Indices. This publication is listed in bibliographic services, including Current Contents ${ }^{\circledR}$ and PubMed/MEDLINE.

Disclaimer. The statements, options and data contained in this publication are solely those of the individual authors and contributors and not of the publisher and the editor(s). The appearance of advertisements in the book is not a warranty, endorsement, or approval of the products or services advertised or of their effectiveness, quality or safety. The publisher and the editor(s) disclaim responsibility for any injury to persons or property resulting from any ideas, methods, instructions or products referred to in the content or advertisements.

Drug Dosage. The authors and the publisher have exerted every effort to ensure that drug selection and dosage set forth in this text are in accord with current recommendations and practice at the time of publication. However, in view of ongoing research, changes in government regulations, and the constant flow of information relating to drug therapy and drug reactions, the reader is urged to check the package insert for each drug for any change in indications and dosage and for added warnings and precautions. This is particularly important when the recommended agent is a new and/or infrequently employed drug.

All rights reserved. No part of this publication may be translated into other languages, reproduced or utilized in any form or by any means electronic or mechanical, including photocopying, recording, microcopying, or by any information storage and retrieval system, without permission in writing from the publisher.

(c) Copyright 2008 by S. Karger AG, P.O. Box, CH-4009 Basel (Switzerland)

www.karger.com

Printed in Switzerland on acid-free and non-aging paper (ISO 9706) by Reinhardt Druck, Basel

ISSN 1420-9519

ISBN 978-3-8055-8548-4 


\section{Contents}

VII Foreword

Egesten, A. (Lund); Schmidt, A. (Witten); Herwald, H. (Lund)

1 From Darwin and Metchnikoff to Burnet and Beyond Cooper, E.L. (Los Angeles, Calif.)

12 General Introduction to Innate Immunity: Dr. Jekyl/Mr. Hyde Quality of the Innate Immune System Zänker, K.S. (Witten)

21 The Innate Immune System of Mammals and Insects Müller, U. (Leipzig); Vogel, P. (Bochum); Alber, G. (Leipzig); Schaub, G.A. (Bochum)

45 Pattern Recognition Receptors and Their Role in Innate Immunity: Focus on Microbial Protein Ligands Areschoug, T. (Lund); Gordon, S. (Oxford)

61 Antimicrobial Peptides in Innate Immune Responses Sørensen, O.E. (Lund); Borregaard, N. (Copenhagen); Cole, A.M. (Orlando, Fla.)

78 Complement: An Efficient Sword of Innate Immunity Rambach, G.; Würzner, R.; Speth, C. (Innsbruck)

101 Antibacterial Chemokines - Actors in Both Innate and Adaptive Immunity Eliasson, M.; Egesten, A. (Lund)

118 The Role of Neutrophils and Monocytes in Innate Immunity Kantari, C. (Paris); Pederzoli-Ribeil, M. (London); Witko-Sarsat, V. (Paris)

147 Innate Immune Functions of the Airway Epithelium Bartlett, J.A.; Fischer, A.J.; McCray Jr, P.B. (lowa City, lowa)

164 Oxidative Innate Immune Defenses by Nox/Duox Family NADPH Oxidases

Rada, B.; Leto, T.L. (Rockville, Md.) 
188 Aging and Impairment of Innate Immunity

Nomellini, V. (Maywood, III.); Gomez, C.R. (Maywood, III./Santiago);

Kovacs, E.J. (Maywood, III.)

206 Author Index

207 Subject Index 


\section{Foreword}

Interestingly, it was not long ago that the area of innate immunity was delineated as a separate entity of immunity, i.e. in contrast to adaptive immunity. Many host defense mechanisms provided by the innate immune system are essential to keep organisms in a state of health, primarily e.g. against potentially harmful microorganisms or aeroplankton present in their environment. In addition to securing the integrity against pathogenic microorganisms of the milieu, vertebrates will have time to mount a specific adaptive immune response owing to innate immune functions. On the other hand, failure of mechanisms involved in innate immunity can contribute to disequilibria, resulting in both infectious and noninfectious diseases such asthma, allergies, and inflammatory bowel disease. The longstanding evolutionary pressure on innate immune mechanisms, as a consequence of host-parasite interactions, can provide keys to how we can tackle future challenges such as bacterial resistance to conventional antibiotics and other antiinfective agents. Therefore, an improved understanding of innate immunity is important to develop novel strategies to combat a broad range of diseases.

Innate immunity is an area of research that is rapidly expanding, and it is rightfully attracting an increasing interest among a broad audience of scientists and clinicians. In the present volume of Contributions to Microbiology, we provide a wide and updated overview on several important mechanisms involved in innate immunity. We have been fortunate to recruit several eminent scientists from around the world, giving overviews in their fields of expertise. It is our belief that this volume will provide interesting and thought-provoking aspects on this ancient and important part of the immune system.

Arne Egesten, Lund Axel Schmidt, Witten Heiko Herwald, Lund 
